\title{
Performance evaluation of Reinforced honeycomb structure under blast load
}

\section{DOI:10.36909/jer.11929}

\author{
Tiju Thomas*, Gaurav Tiwari* \\ *Department of Mechanical Engineering, Visvesvaraya National Institute of Technology, \\ Nagpur, INDIA-440010 \\ Email id: tiju.thomas30@gmail.com
}

\begin{abstract}
In this study, numerical simulations were carried out to explore the response of the reinforced honeycomb sandwich structure with varying cell size $(7,10$ and $15 \mathrm{~mm})$, node length $(25,37.5$ and $50 \mathrm{~mm})$ and cell wall thickness $(0.1,0.2,0.3$ and $0.4 \mathrm{~mm})$. The honeycomb structure made of aluminum alloy 8011 were subjected to low intensity blast loads by varying mass of TNT (10 $\mathrm{g}, 15 \mathrm{~g}, 20 \mathrm{~g}$ and $25 \mathrm{~g}$ ) and standoff distance $(200 \mathrm{~mm}, 250 \mathrm{~mm}$ and $300 \mathrm{~mm})$. Commercial finite element code LS-DYNA was employed to carry out numerical simulations for both conventional and reinforced honeycomb sandwich structure keeping identical geometrical and blast load parameters. The deformation of the back face sheet was a major parameter to establish blast resistance of the core. Failure mechanisms of reinforced honeycomb was characterized as fully folded region, partially folded region, and clamped region. Reinforced honeycomb sandwich outperformed the conventional honeycomb sandwich structure of identical geometry parameters under similar blast loads. Increase in cell-wall thickness and node length enhanced the blast resistance whereas, increment in cell size reduced the blast resistance of the reinforced honeycomb sandwich structure.
\end{abstract}

Keywords: Honeycomb, Reinforcement, Blast loading, LS-DYNA 


\section{INTRODUCTION}

The analysis of the civilian and military structure against blast load, where a very high impulse of the pressure hit the structure has gained popularity in recent times mainly due to accidental or terrorist causes. Therefore in recent years, a major emphasis is to obtain the blast response of the target made of different materials such as steel plates, composite plates, aluminum plate, window glass and laminated glass [Mosert 2018, K Amini et al. 2017, A Gargano et al. 2017, K Spiller et al. 2016, P Del linz et al. 2017 \& Bai et al. 2017]. The light weight sandwich structure having core in the form of foam, honeycombs, lattice and special porous structure have drawn the attention of the many researchers due to its high strength to weight ratio [Marx et al. 2018, Zhang et al. 2015, Yuan et al. 2018, Mcshaen et al. 2010, Jing et al. 2014, Liu et al. 2014 \& Aleyaasin et al. 2015]. Furthermore, structure with honeycomb core was found superior in comparison with other structures [Theobald et al. 2010].

Li et al. 2014, presented three modes of failure of aluminium hexagonal cores during blast loading. Large inelastic deformation occurred at the point of contact of pressure impulse, large plastic deformation, erosion and tensile tearing at the boundary were observed as failure modes. Furthermore, Zhu et al., 2008, elucidated modes of failure of front and back face sheets and honeycomb core separately. Global bending, crushing of core and micro-buckling were perceived during uniform loaded and localized loaded blast [Nurick et al. 2009]. Langdon et al. 2010, reported that the composite facesheet honeycombs had higher blast resistance than the aluminium facesheet honeycomb. Apart from core crushing, shearing and debonding were also major forms of failure in the composite face sheet honeycomb. Core thickness enhancement and 
increase in facesheet thickness resulted in increase in core densification time thus, increased the blast resistance [Chi et al. 2010]. Fan et al. 2016, investigated blast resistance of aluminium honeycomb sandwich structure subjected to underwater explosion. Honeycomb sandwich structure performed much better than the monolithic plate of identical thickness. Denser honeycomb cores offered better resistance against blast loads [Dharamsena et al. 2008 \& Huang et al. 2016]. Different numerical modeling techniques like homogenization of solid plate incorporated with orthogonal properties and modeling of quarter sandwich plate were performed to reduce computational time and effort and attain deformation pattern of face sheet and core [Karagiozava et al. 2009, Qi et al. 2017 \& Zhu et al. 2009]. Moreover, Ebrahimi et al. 2016 \& 2018 applied shock load followed by projectile impact (different angle of incidence) to honeycomb core. It was evident that various special structures were investigated under blast loads to evaluate its performance and attain highly efficient blast resistant structure. Qi et al. 2017, found that auxetic honeycomb [Zhang et al. 2013 \& Zheng et al. 2018] performs better than conventional honeycomb. Moreover, graded auxetic honeycomb core and cross arranged honeycomb were more effective in blast energy absorption than conventional honeycomb [Jin et al. 2016, Li et al. 2018, Wang et al. 2018, Rong et al. 2017 \& You et al. 2016]. Even graded hexagonal honeycomb panels were also having higher blast resistance than the conventional one [Li et al. $2016 \& 2017]$.

Despite, wide applicability of the honeycomb structure in the aerospace, automotive, railway and ship building industries, a very few studies found in the literature addresses the advancement of the reinforced honeycomb structure pertaining to enhancement in the energy absorption capacity of the structure can be increased. Moreover, the blast response of the honeycomb structure has 
also been reported in the limited studies. Therefore, in-depth study is required to know the behavior of the reinforced honeycomb structure against blast loading.

In this paper, the numerical simulation was carried out to explore the response of aluminium reinforced honeycomb structure against blast loads. Moreover, it is compared with conventional honeycomb structure to understand the effectiveness of the reinforcement. Deformation of core and back face sheet deflection for both structures were considered as major parameter for determining blast resistance of the structures.

\section{NUMERICAL MODELING}

A reinforced honeycomb [Tiwari et al. 2018, He et al. 2015, Thomas et al. 2019, Thomas et al. 2018] is a core with reinforced layer in between each individual layer of conventional hexagonal honeycomb, see Fig 1. Reinforced honeycomb core was modeled with varying cell size $7 \mathrm{~mm}, 10$ $\mathrm{mm}$, and $15 \mathrm{~mm}$ respectively. While cell wall thickness was taken as $0.1,0.2,0.3$ and $0.4 \mathrm{~mm}$ respectively. Further, node length was also varied as $25 \mathrm{~mm}, 37.5 \mathrm{~mm}$ and $50 \mathrm{~mm}$ respectively. Honeycomb core was sandwiched between aluminium facesheets of $0.5 \mathrm{~mm}$ and $1 \mathrm{~mm}$ thickness respectively. Similarly, the reinforced honeycomb sandwich core was developed with varying cell size 7, 10 and $15 \mathrm{~mm}$, cell wall thickness $0.1,0.2,0.3$ and $0.4 \mathrm{~mm}$ and node length $25,37.5$ and $50 \mathrm{~mm}$ respectively. Honeycomb core was sandwiched between aluminium facesheets of 0.5 $\mathrm{mm}$ and $1 \mathrm{~mm}$ thickness respectively. Three-dimensional surface model was developed in SOLIDEDGE, further, imported into commercial finite element code LS-DYNA. The model subsequently was meshed with fully integrated $0.5 \mathrm{~mm}$ sized shell elements to reduce hourglass energy. Facesheets used for sandwiching honeycomb core was also meshed with fully integrated shell elements of same size. Automatic surface to surface contact was assigned between 
facesheets and honeycomb core. Sliding static and dynamic friction coefficients between the surfaces were allocated as 0.6. Both face sheets and honeycomb core were ascribed aluminium alloy 8011 properties. Mat 024 (MAT_PIECEWISE_LINEAR_PLASTICITY) was utilized for attributing material properties to the honeycomb core and face sheet, see Table1. The yielding function criterion was expounded as [Tabacu 2018, Hallquist 2006]:

$\phi=\frac{1}{2} * S_{a b} * S_{a b}-r_{y}^{2} \leq 0$

$r_{y}=\beta *\left[\sigma_{0}+f_{h}\left(\varepsilon_{e f f}^{p}\right)\right]$

$\Phi=$ Yielding function

$\mathrm{S}_{\mathrm{ab}}=$ Deviotric stress

$r_{y}=$ Current radius of Yield Surface

$\sigma_{\mathrm{o}}=$ Flow stress, $f_{h}\left(\varepsilon_{e f f}^{p}\right)=$ Hardening function

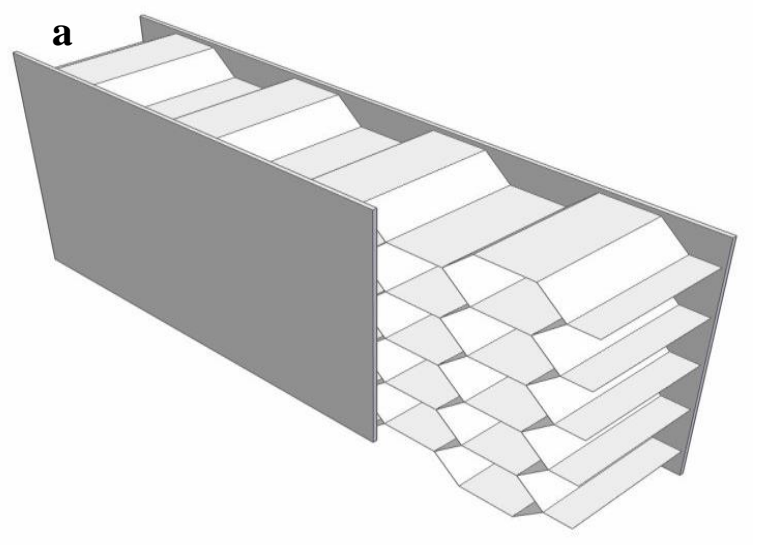

b

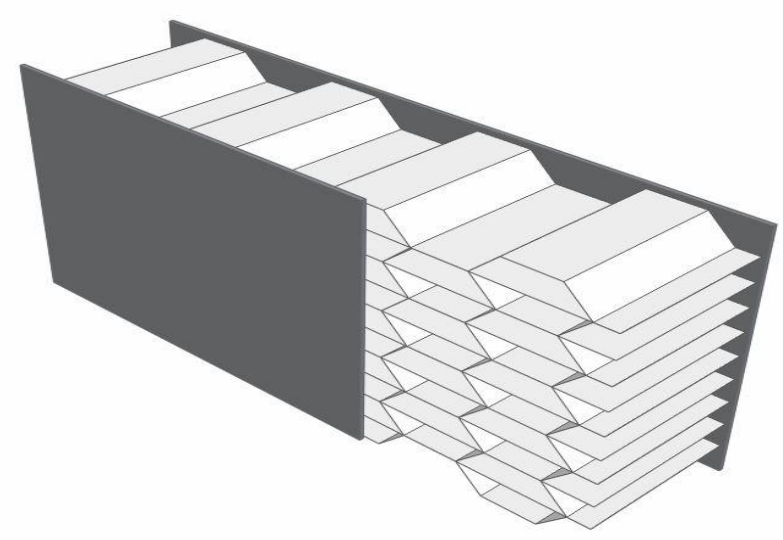




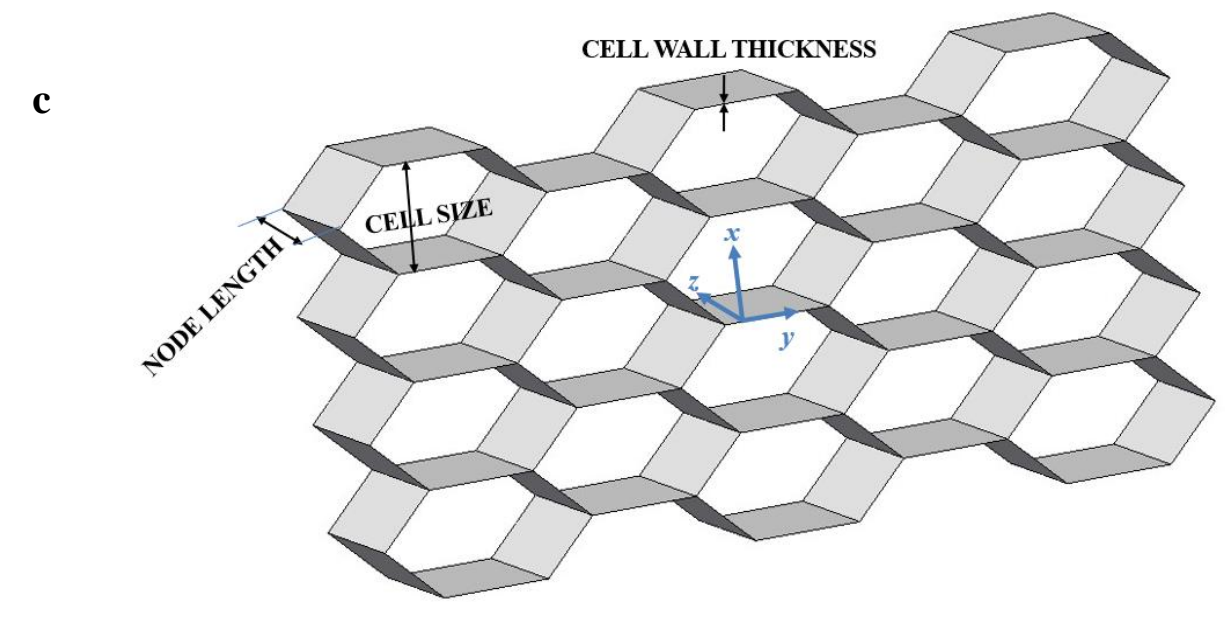

Figure 1 a) Honeycomb sandwich, b) Reinforced honeycomb Sandwich, c) Nomenclature of honeycomb

Table 1 Material properties of AA 8011

\begin{tabular}{|l|c|}
\hline Property & Value \\
\hline Modulus of Elasticity & $69 \mathrm{GPa}$ \\
\hline Poisson's ratio & 0.3 \\
\hline Density & $2720 \mathrm{~kg} / \mathrm{m}^{3}$ \\
\hline Ultimate tensile strength & $145.28 \mathrm{MPa}$ \\
\hline Yield Strength & $98.147 \mathrm{MPa}$ \\
\hline
\end{tabular}

Conwep blast loading with spherical air burst model was applied on the sandwich structures after applying initial boundary conditions to simulate blast loading conditions. Blast segment was assigned to the outer face of face sheet which interacts directly with blast waves.

\section{RESULTS AND DISCUSSION}


Blast analysis of reinforced honeycomb sandwich core was performed using commercial finite element code LS-DYNA. Numerical model was validated by employing steel plate subjected to blast loads with Load_Blast_Enhanced keycard [Ngo et al. 2007, Goel et al. 2012] and comparing the results available in literature. Furthermore, same blast technique was incorporated in honeycomb sandwiched model to attain deformation modes and failure mechanisms, which were compared with literature.

Table 2. Numerical models developed for study

\begin{tabular}{|c|c|c|c|}
\hline S No. & Model & Geometrical parameters & Significance \\
\hline 1 & Monolithic Plate & $\begin{array}{c}\text { Length, Width and } \\
\text { thickness }\end{array}$ & $\begin{array}{l}\text { For validating blast } \\
\text { load parameters in } \\
\text { numerical model }\end{array}$ \\
\hline 2 & Conventional Honeycomb & $\begin{array}{l}\text { Core thickness (Node } \\
\text { length), Cell size and } \\
\text { Facesheet thickness }\end{array}$ & $\begin{array}{c}\text { For comparing } \\
\text { performance with } \\
\text { reinforced } \\
\text { honeycomb }\end{array}$ \\
\hline 3 & Reinforced Honeycomb & $\begin{array}{l}\text { Core thickness (Node } \\
\text { length), Cell size and } \\
\text { Facesheet thickness }\end{array}$ & $\begin{array}{c}\text { For attaining } \\
\text { performance of } \\
\text { reinforced } \\
\text { honeycomb against } \\
\text { blast loads }\end{array}$ \\
\hline
\end{tabular}




\section{CALIBRATION OF NUMERICAL MODEL}

Numerical model of blast loading was calibrated using a mild steel plate modeled with the configuration used by Mehreganian et al. 2018. Mild steel plates of $400 \mathrm{~mm} \times 400 \mathrm{~mm} \times 4.6 \mathrm{~mm}$ were subjected to blast load generated by $25 \mathrm{~g}$ PE4 at stand-off distance of $38 \mathrm{~mm}$. A symmetric plate meshed with fully integrated shell elements with hourglass control and two ends of the plate were fixed with no allowable rotations and translations while two other ends were assigned symmetric boundary conditions see Figure 2 (a). Load_Blast_Enhanced keycard was used for allotting blast loading effect to the plate to the assigned blast segment (lower face of plate upon which blast loads will interact).

$\mathbf{a}$

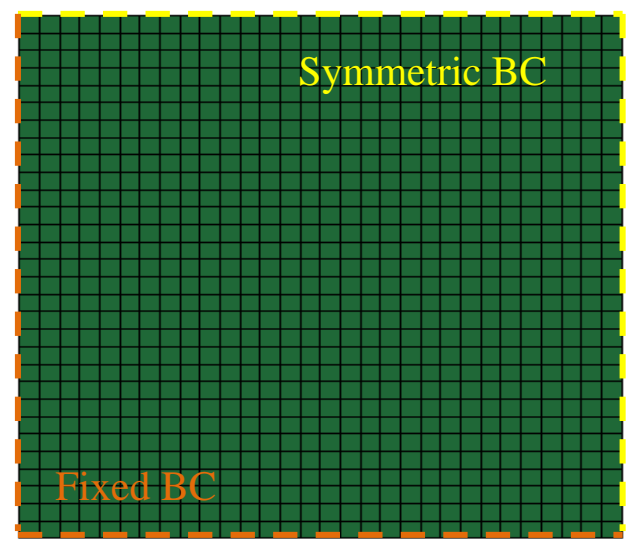

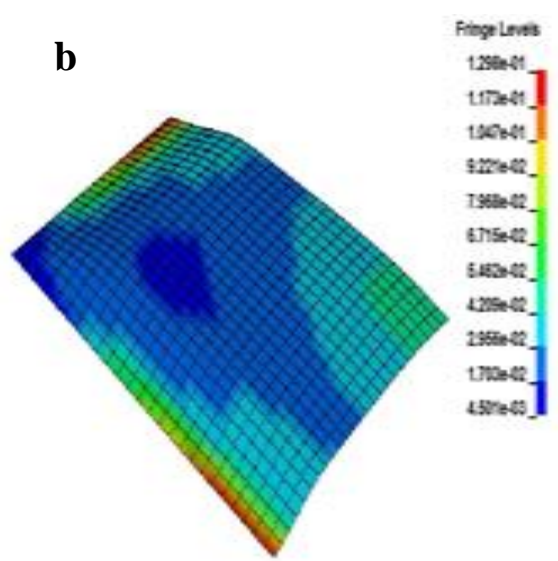

Figure 2 a) Boundary conditions of plate b) Equivalent plane strain for present model

Material model MAT_024 was used for providing material properties of mild steel (Yield stress $\sigma_{\mathrm{o}}=350 \mathrm{MPa}$, Modulus of elasticity $\mathrm{E}=200 \mathrm{GPa}$ and Ultimate strength $\sigma_{\mathrm{ut}}=400 \mathrm{MPa}$ ) to plate. After simulations, generated impulse was approximately equivalent to simulated result of 
Mehreganian et al. 2018. In this study, Maximum deflection at the center of the plate was 3.6 mm while $3.53 \mathrm{~mm}$ was deflection for Mehreganian et al. 2018, (see Table 2)

Table 3. Comparison of deflection between Mehreganian et al. 2018 model and present model

\begin{tabular}{|c|c|c|c|}
\hline Mass (gm) & Deflection [44] (mm) & $\begin{array}{c}\text { Deflection [present } \\
\text { model] }(\mathbf{m m})\end{array}$ & \% error \\
\hline 25 & 3.53 & 3.6 & 1.94 \\
\hline 33 & 10.5 & 10.64 & 1.31 \\
\hline 40 & 12.72 & 12.85 & 1.012 \\
\hline
\end{tabular}

It was observed that reflected pressure was insignificant and total pressure was equivalent to incident pressure acting on plate. Maximum pressure on the plate was defined by KingeryBulmash equations [Tabacu 2018, Hallquist 2006],

$$
P=P_{i}\left[1-\frac{t-t_{a}}{t_{p}}\right] \exp \left[-\frac{a\left(t-t_{a}\right)}{t_{p}}\right]
$$

Where, $P_{i}=$ Incident Pressure

$\mathrm{t}_{\mathrm{a}}=$ Time of approach

$\mathrm{P}=$ Total Reflected Pressure

$t_{p}=$ Positive phase duration

$\mathrm{a}=$ Exponential decay factor for incident wave 
Impulse generated in the structure by the blast pressure was the most prominent factors for deciding the maximum deformation in the structure. Impulse was obtained by the area under the pressure time graph. The nature of curve for pressure time graph was triangular shape and area under such curve was described by positive impulse on the structure, see Figure 3 (b). Therefore, Impulse of the structure was expressed as,

$$
I=\frac{1}{2} P_{i} t_{a}
$$

Where, I = Impulse of blast

$\mathrm{P}_{\mathrm{i}}=$ Incident Pressure

$\mathrm{t}_{\mathrm{a}}=$ Time of approach

Conwep program has utilized the above equation in developing computational software program. Thus, pressure interacting with the plate or surface was calculated mathematically which was further compared with pressure attained from simulations. It was evident that pressures and impulses obtained through both methods were quite close to each other, see Figure 3. 

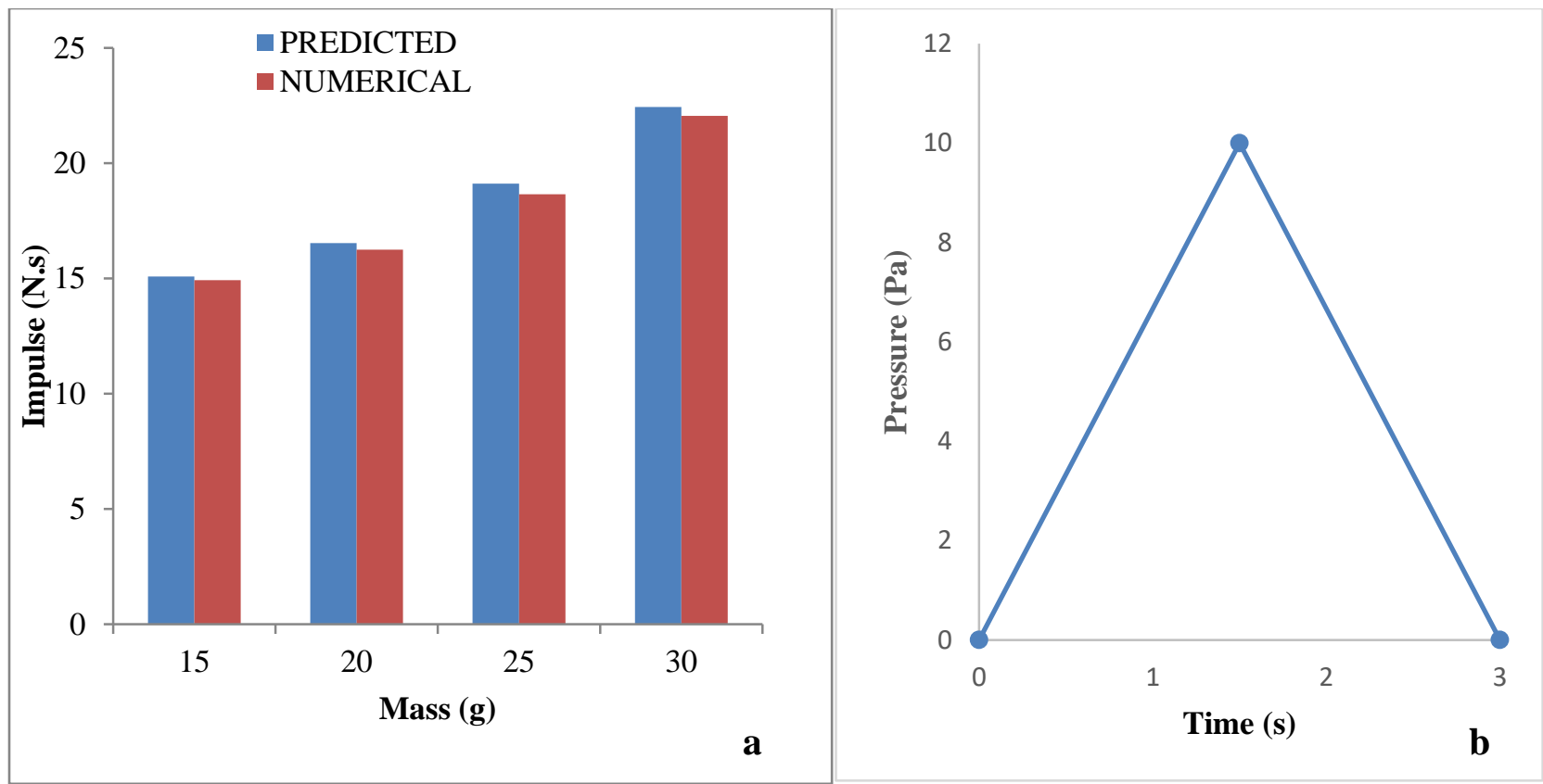

Figure 3. Comparison between a) Predicted and simulated Impulse on structure, b) Pressure-time graph for $15 \mathrm{~g}$ TNT

\section{HEXAGONAL HONEYCOMB SANDWICH}

After calibration of model for blast pressure applicable on the surface of plate, blast loads were further applied to honeycomb sandwich citing similar approach and applying boundary conditions, see Figure 4. It was manifested that modes of deformation of honeycomb sandwich structure obtained in simulations were equivalent to the modes of deformation defined in literature. Front and back facesheet deformed on the action of blast load while honeycomb core show crushing and densification characteristics due to which back facesheet deformation was lesser than front face sheet deformation [Nurick et al.2009, Langdon et al. 2010, Chi et al. 2010]. 


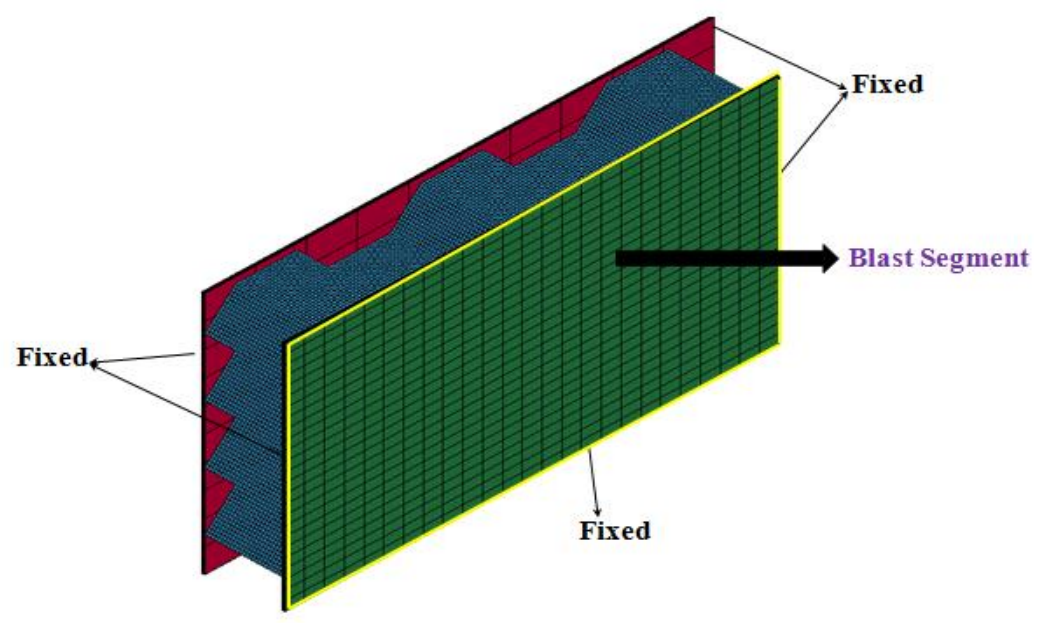

Figure 4 Boundary conditions applied on honeycomb sandwich core
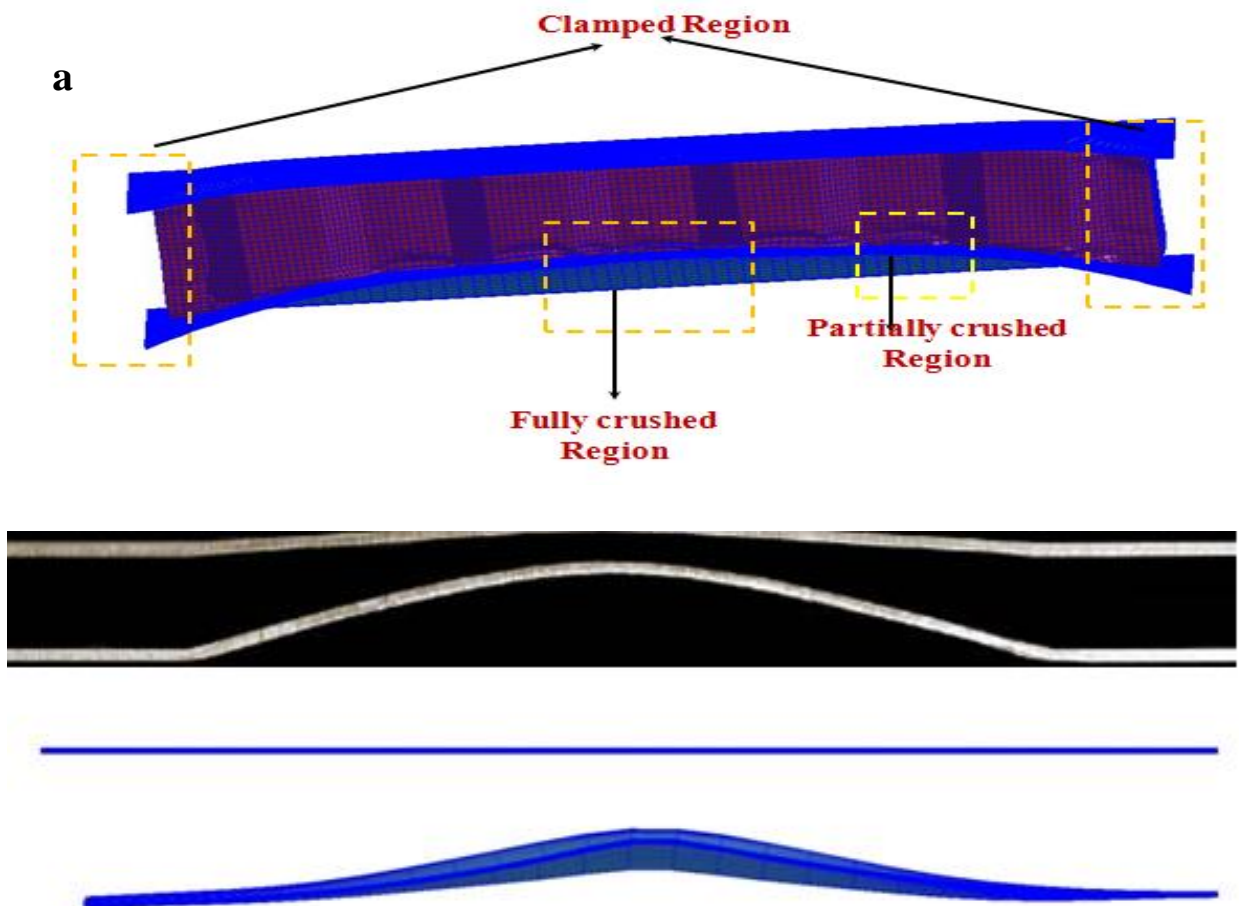

b

Figure 5 a) Modes of deformation of honeycomb, b) Deformation of facesheets 
Honeycomb core absorbs energy while crushing and densification leading to inferior energy influence on back facesheet. Debonding of facesheets and honeycomb core and partial tearing of sandwich around boundary condition was also observed during deformation of honeycomb sandwich [Li et al., 2014]. Honeycomb failure region was defined as fully folded region, partially folded region, and clamped region, see Figure 5.

Furthermore, Reinforced honeycomb sandwich and conventional honeycomb sandwich structures were compared with each other in terms of modes of deformation and performance of cores against blast loads.

\section{MODES OF DEFORMATION}

Reinforced honeycomb sandwich structure performed better than conventional honeycomb sandwich structure under equivalent blast loads. Relative density (core density) of reinforced honeycomb was more than conventional honeycomb subsequently reflecting in higher blast resistance of reinforced honeycomb. Modes of deformation of reinforced honeycomb core were found like conventional honeycomb core [Nurick et al.2009, Langdon et al. 2010, Chi et al. 2010]. Since, the blast waves acts substantially at the mid portion of the facesheet. Therefore, it was clearly notable that central portion of the reinforced honeycomb sandwich plate was deformed on comparison with other portions of the facesheet. Debonding between facesheets and reinforced honeycomb was perceived at the central portion.

Furthermore, Reinforced honeycomb core undergoes crushing and densification at the central portion. The regions of deformation of reinforced honeycomb core were characterized into three broad regions namely, see Figure 6- 
Fully folded region - Central portion of plate encountered most of blast waves leading to high deformation of facesheets with crushing (progressive folding) of reinforced honeycomb core.

Partially folded region - folding density of honeycomb was reduced due to reduction in the intensity of blats loads.

Clamped region - Surrounding boundary condition where the plate was minimal effected by blast loading.

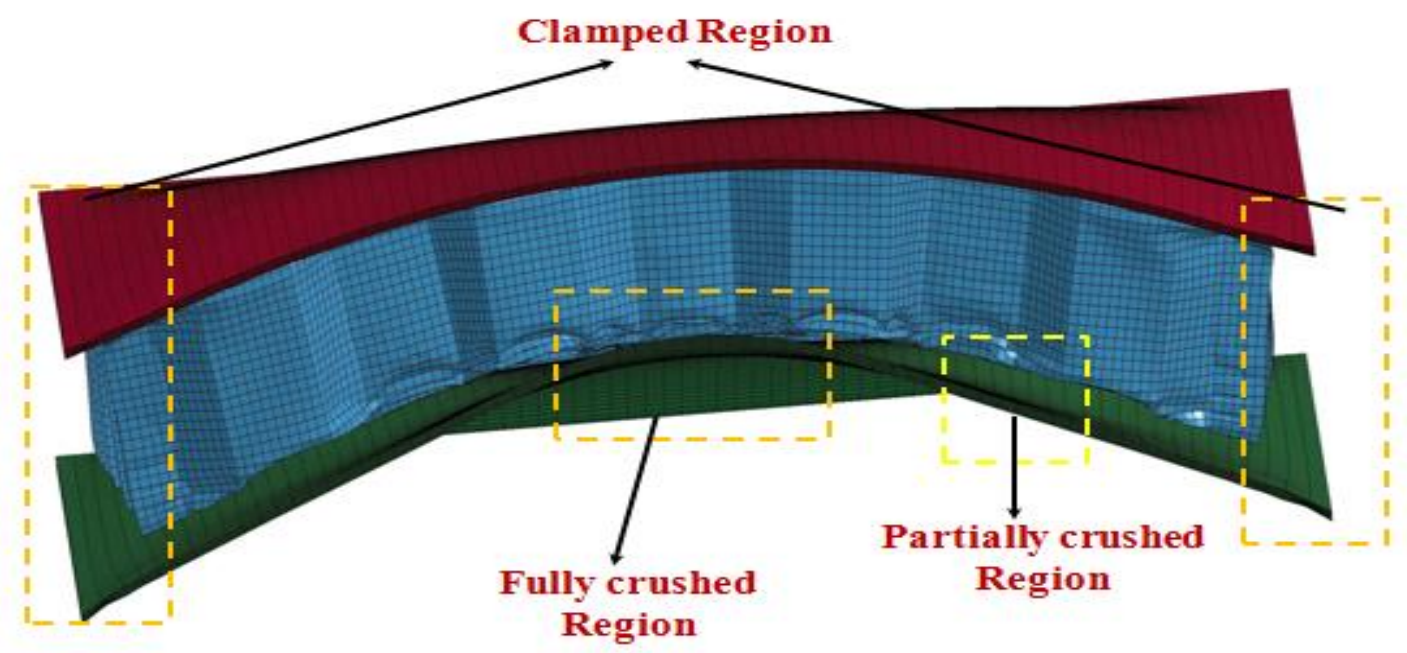

Figure 6 Modes of deformation of Reinforced honeycomb sandwich

\section{BLAST RESISTANCE}

Although deformation modes of both conventional [Nurick et al.2009, Langdon et al. 2010, Chi et al. 2010, Dharmasena et al. 2008] and reinforced honeycombs were quite analogous to each other. But intensity of crushing and densification of conventional honeycomb was more as compared to that of reinforced honeycomb when subjected to equivalent blast loads. Back facesheet deflection was most critical criteria for deciding blast resistance of the sandwich structure. In this study, Back facesheet deflection of reinforced honeycomb sandwich plate was considerably less as 
compared to Back facesheet deflection of conventional honeycomb sandwich plate. Reinforced and conventional honeycomb core with $10 \mathrm{~mm}$ cell size, $25 \mathrm{~mm}$ node length, $0.1 \mathrm{~mm}$ cell-wall thickness and $1 \mathrm{~mm}$ thick face sheets were subjected to blast loads with different TNT masses 10, 15, 20 and $25 \mathrm{gm}$ respectively exploding at standoff distance $200 \mathrm{~mm}$. Deformation of reinforced honeycomb back facesheet was $2.84 \mathrm{~mm}$ while that of conventional honeycomb back facesheet was $4.38 \mathrm{~mm}$ when subjected to $10 \mathrm{~g}$ TNT explosion. In the same way reinforced honeycomb had 3.63, 4.5 and $4.7 \mathrm{~mm}$ deformation while conventional honeycomb had 5.46, 6.8 and $7.2 \mathrm{~mm}$ deformation when subjected to 15,20 and $25 \mathrm{~g}$ respectively. It was observed that reinforced honeycomb core has $36.67 \%, 36.067 \%, 35.603 \%$ and $35.919 \%$ less back face sheet deformation than conventional honeycomb when subjected to explosion of $10,15,20$ and $25 \mathrm{~g}$ TNT respectively, see Table 3. Energy absorbed by reinforced honeycomb core was also evidently higher on comparison with conventional honeycomb core.

Table 4. Comparison of deformation between honeycomb and reinforced honeycomb

\begin{tabular}{|c|c|c|c|c|}
\hline $\begin{array}{l}\text { Mass } \\
\text { (g) }\end{array}$ & & $\begin{array}{l}\text { BFS } \\
(\mathbf{m m})\end{array}$ & $\begin{array}{c}\mathrm{RC} / \mathrm{HC} \\
(\mathrm{mm})\end{array}$ & FFS (mm) \\
\hline \multirow[b]{2}{*}{10} & Reinforced HC & 2.84 & 3.34 & 4.2 \\
\hline & $\begin{array}{l}\text { Conventional } \\
\mathrm{HC}\end{array}$ & 4.38 & 4.52 & 4.9 \\
\hline \multirow[b]{2}{*}{15} & Reinforced HC & 3.62 & 4.49 & 5.1 \\
\hline & $\begin{array}{l}\text { Conventional } \\
\mathrm{HC}\end{array}$ & 5.46 & 6.25 & 6.79 \\
\hline 20 & Reinforced HC & 4.5 & 5.2 & 6.46 \\
\hline
\end{tabular}




\begin{tabular}{|c|l|c|c|c|}
\hline \multirow{2}{*}{25} & Conventional & 6.8 & 7.4 & 8.79 \\
\hline \multirow{2}{*}{25} & Reinforced HC & 4.7 & 5.8 & 6.96 \\
\cline { 2 - 5 } & Conventional & & & \\
& HC & 7.2 & 8.1 & 9.3 \\
\hline
\end{tabular}

\section{PARAMETERS AFFECTING PERFORMANCE OF REINFORCED HONEYCOMB:}

Blast performance of reinforced honeycomb core was contributed by various geometrical parameters like cell size, cell wall thickness and node length. Blast performance was also dependent on blast parameters such as mass of explosive and position or distance of explosive from test sample. Further, this study elaborates in details effect of all such parameters on the performance of reinforced honeycomb core.

\section{EFFECT OF CELL-WALL THICKNESS}

Reinforced honeycomb cores with different cell-wall thicknesses $0.1,0.2,0.3$ and $0.4 \mathrm{~mm}$ with constant cell size $10 \mathrm{~mm}, 1 \mathrm{~mm}$ facesheet thickness and node length $25 \mathrm{~mm}$ were subjected to blast loads generated from $10 \mathrm{~g}$ TNT with $200 \mathrm{~mm}$ standoff distance. Cell-wall thickness influences the strength and core density of reinforced honeycomb. Blast resistance of reinforced honeycomb increased with increase in cell-wall thickness of reinforced honeycomb, similar observation was also perceived for conventional honeycombs [Li. et al. 2014]. This is primarily due to enhancement in strength, core density and energy absorbing capacity of reinforced honeycomb on cell-wall thickness increment. Reinforced honeycomb core with higher cell-wall thickness absorbs more energy, consequently leading to lower back facesheet deformation. 
Reinforced honeycomb core sandwich with $0.4 \mathrm{~mm}$ thickness tends to have back face sheet deformation of $1.79 \mathrm{~mm}$ while with $0.1 \mathrm{~mm}$ thickness deformation was $4.9 \mathrm{~mm}$. Difference between front and back facesheet deformation was increased from $24.15 \%$ to $56.34 \%$ with increase in cell-wall thickness from 0.1 to $0.4 \mathrm{~mm}$, Fig.7.

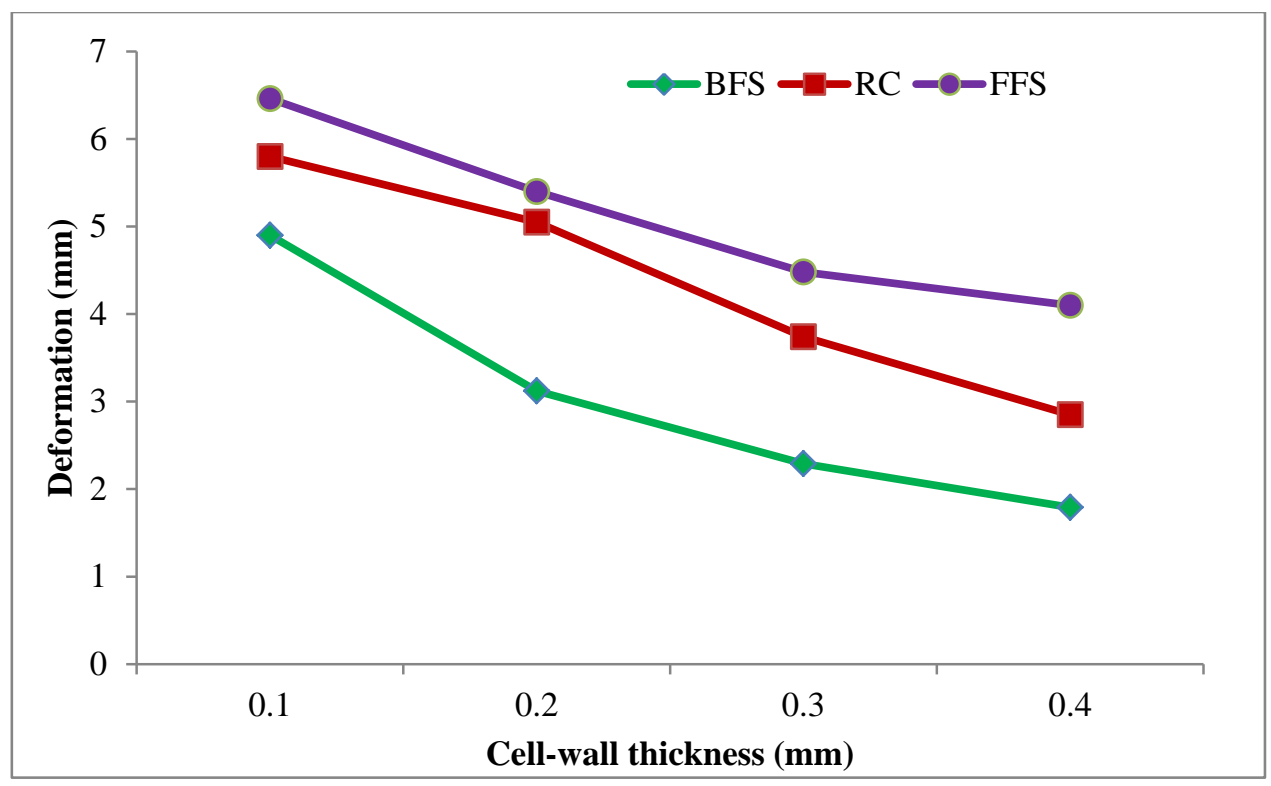

Figure 7. Variation in deformation of reinforced honeycomb sandwich with cell wall thickness

\section{EFFECT OF CELL SIZE:}

Reinforced honeycomb core with varying cell sizes 7,10 and $15 \mathrm{~mm}$ respectively and constant $25 \mathrm{~mm}$ node length, $0.1 \mathrm{~mm}$ cell-wall thickness and $1 \mathrm{~mm}$ facesheet were modeled with blast loads developed by detonation of $10 \mathrm{~g}$ TNT at $200 \mathrm{~mm}$ distance from front facesheet (FFS). It was observed that reinforced honeycomb core (RC) with smaller cell sizes performs better under dynamic blast loads. Back facesheet (BFS) deformation of $7 \mathrm{~mm}$ cell size reinforced honeycomb core was $4.9 \mathrm{~mm}$ while $6.2 \mathrm{~mm}$ and $6.9 \mathrm{~mm}$ respectively for 10 and $15 \mathrm{~mm}$ cell size cores. Increment in cell size enhances the relative density of reinforced honeycomb core which further 
improves the crushing strength of core. Enhancement in crushing strength of core leads to higher energy absorption capability, see Figure 8.

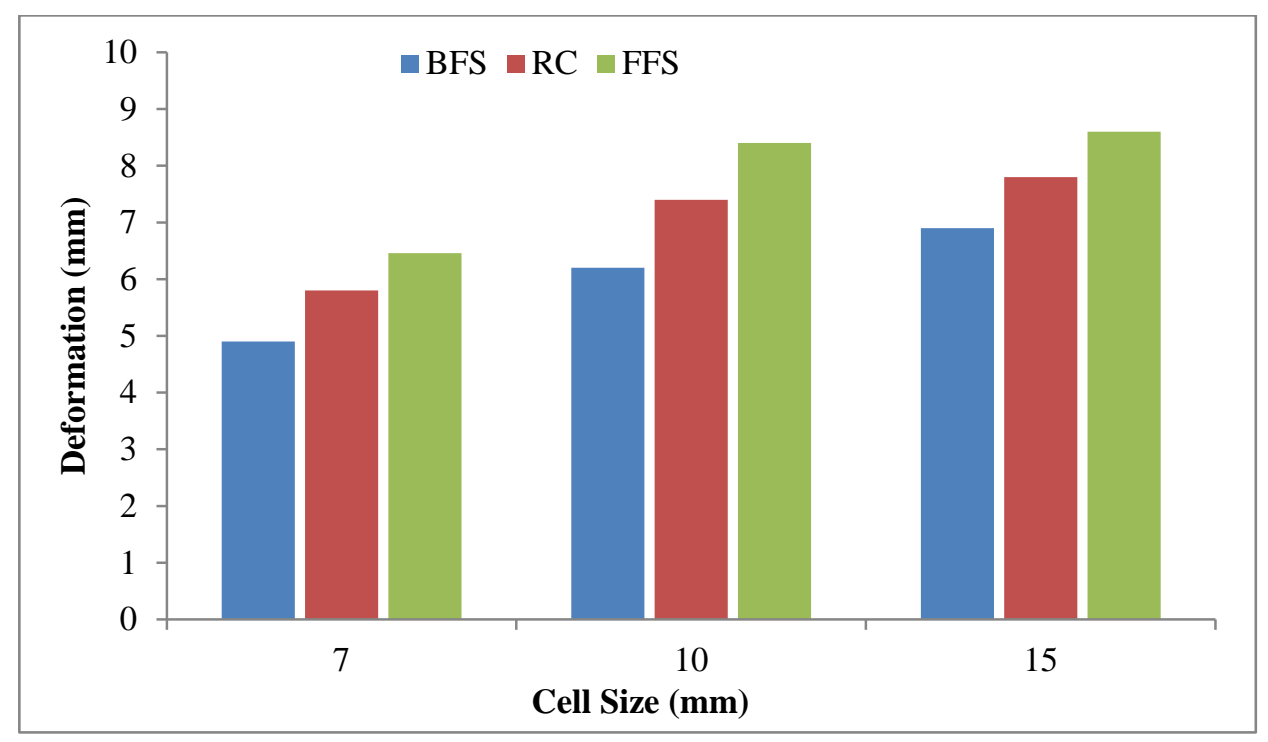

Figure 8 Variation of deformation of reinforced honeycomb core with cell size

\section{EFFECT OF NODE LENGTH (CORE THICKNESS)}

Reinforced honeycomb with different node length as 25, 37.5 and $50 \mathrm{~mm}$ respectively with same cell-wall thickness of $0.1 \mathrm{~mm}$, facesheet thickness $1 \mathrm{~mm}$ and $10 \mathrm{~mm}$ cell size were employed against blast loads of $10 \mathrm{~g}$ TNT with $200 \mathrm{~mm}$ standoff distance. Node length was found to be in proportion with blast resistance, same result was also valid in case of conventional honeycomb [ Langdon et al. 2010]. Back face sheet deformation of reinforced honeycomb with $50 \mathrm{~mm}$ node length was $3.2 \mathrm{~mm}$ while that of $25 \mathrm{~mm}$ node length was $4.9 \mathrm{~mm}$. Back facesheet deflection reduces when node length of reinforced honeycomb increases, see Fig. 9. Because of increase in core thickness, distance between facesheets increases resulting in more crushing length and energy absorbing characteristics of reinforced honeycomb. Subsequently leading to enhancement of diminishing characteristics of blast energy of TNT. 


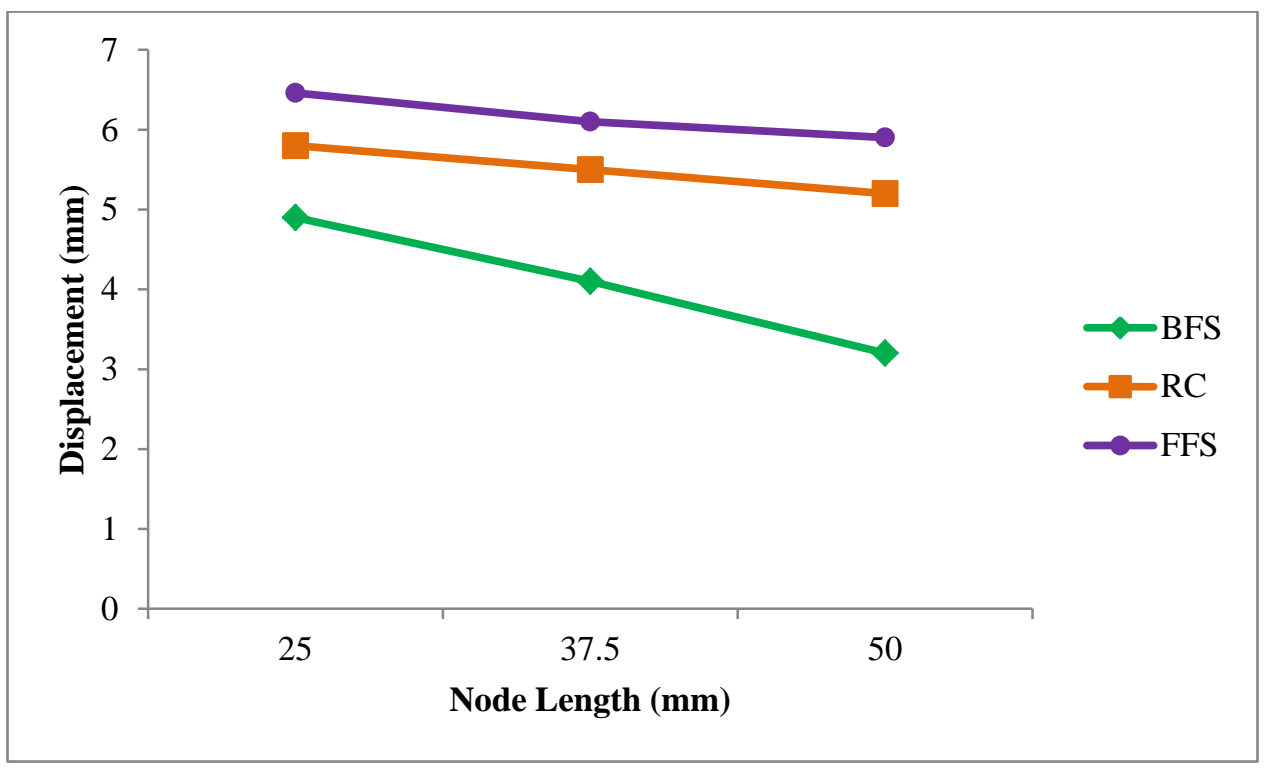

Figure 9. Variation in deformation of reinforced honeycomb core with node length EFFECT OF MASS OF EXPLOSIVE

Reinforced honeycomb sandwich plate with $10 \mathrm{~mm}$ cell size, $0.1 \mathrm{~mm}$ cell wall-thickness, $1 \mathrm{~mm}$ facesheets thickness and $25 \mathrm{~mm}$ node length were imposed to different masses of explosives (TNT) 10, 15, 20, 25 and $30 \mathrm{~g}$ respectively with same stand-off distance of $200 \mathrm{~mm}$. Back facesheet deformation increases from $2.24 \mathrm{~mm}$ to $2.46 \mathrm{~mm}$ on increase of mass of TNT from 10 $\mathrm{g}$ to $30 \mathrm{~g}$. It was evident that increase in the mass of explosive enhances the intensity of the blast pressure acting on the sandwich plate, see Fig 10. Energy absorption of front facesheet and reinforced core increased with increase in mass of explosives used. Increased pressure developed due to increase in mass of TNT subsequently induces more deformation in the front and back facesheet of the reinforced honeycomb sandwich plate. 


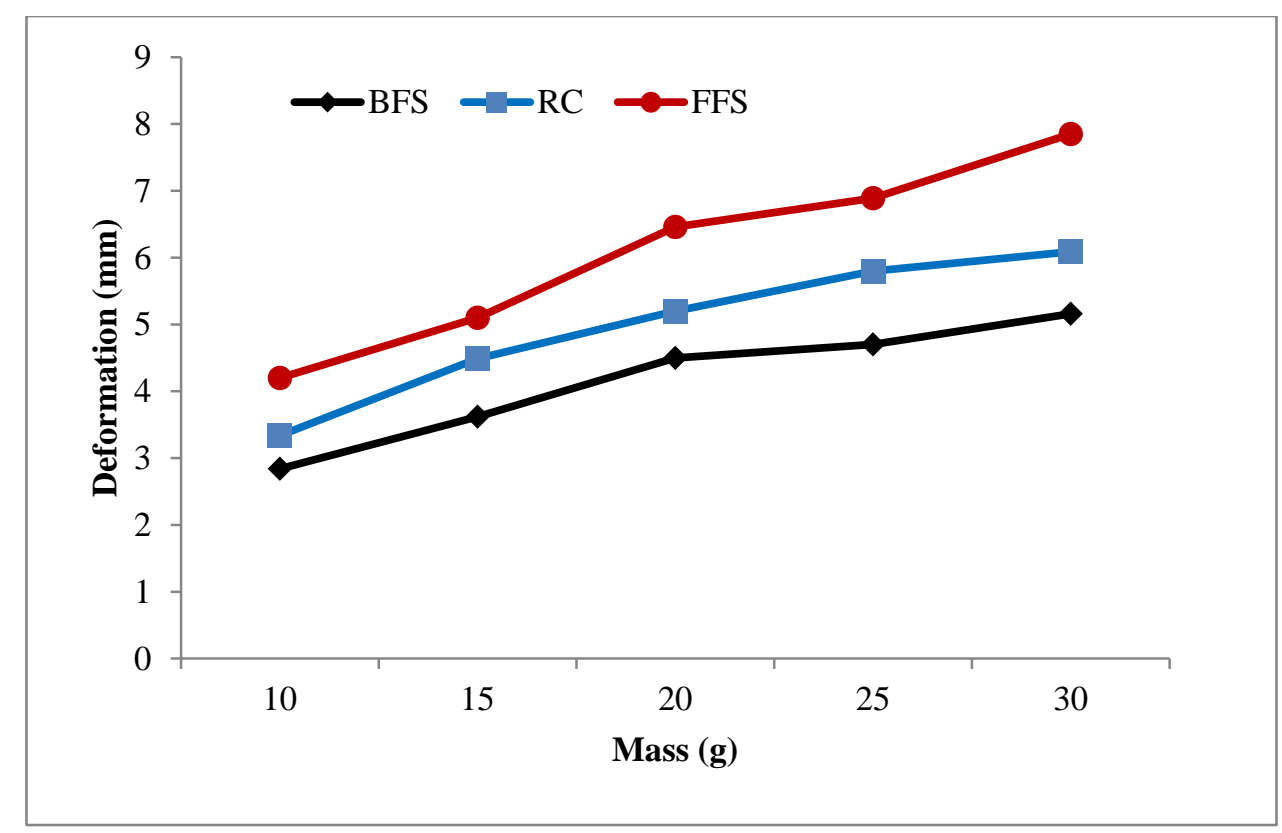

Figure 10 Variation in deformation of reinforced honeycomb core with mass of TNT

\section{EFFECT OF DISTANCE OF DETONATION}

Reinforced honeycomb core of $10 \mathrm{~mm}$ cell size, $25 \mathrm{~mm}$ node length and $0.1 \mathrm{~mm}$ cell wall thickness sandwiched between $1 \mathrm{~mm}$ facesheets were instigated by $10 \mathrm{~g}$ TNT placed at 150, 200, 250,300 and $350 \mathrm{~mm}$ respectively.

Increase in distance of detonation from plate reduces the incident pressure acting on the surface of plate. Enhancement in distance of detonation also reduces the back facesheet deflection but higher magnitude pressure was incident on front face sheet leading to higher front facesheet deflection. Back face sheet deflection was considerably reduced on comparison to front face sheet deflection on increase of standoff distance of detonation. Increase in distances from 150 to $350 \mathrm{~mm}$ were increases the difference between front and back facesheet deflection from $48.9 \%$ to $76.77 \%$. For standoff distance $150 \mathrm{~mm}$ Front facesheet deflection was $18.4 \mathrm{~mm}$ while back 
facesheet deflection was $9.4 \mathrm{~mm}$ with honeycomb deflection $14.6 \mathrm{~mm}$. Similarly for standoff distance $350 \mathrm{~mm}$ Front facesheet deflection was $12.7 \mathrm{~mm}$ while back facesheet deflection was $2.95 \mathrm{~mm}$ with honeycomb deflection $7.6 \mathrm{~mm}$, see Fig. 11.

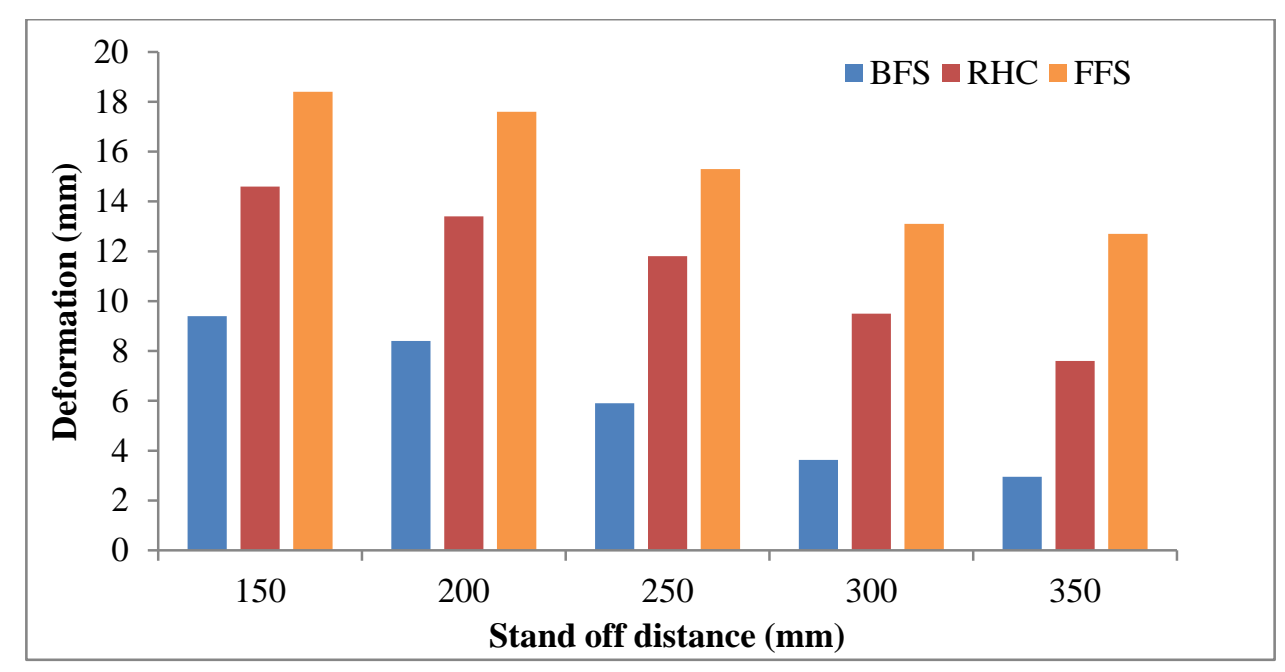

Figure 11. Variation in deformation of reinforced honeycomb core with standoff distance

\section{EFFECT OF FRONT FACE SHEET THICKNESS}

Face sheet plays a major role in energy absorbing of blast waves and offer high blast resistance to the structure. It was observed that increment in the facesheet thickness enhances the blast resistance of the reinforced honeycomb sandwich structure. Reinforced honeycomb sandwich with higher facesheet thickness tends to have lower back facesheet deflection. Reinforced honeycomb with facesheet thickness $1 \mathrm{~mm}$ has back facesheet deformation of $4.9 \mathrm{~mm}$ while that of 6.5 for $0.5 \mathrm{~mm}$ back facesheet thickness. Percentage difference between front and back face sheet deformation was $24.14 \%$ for $1 \mathrm{~mm}$ facesheet thickness while $15.39 \%$ for $0.5 \mathrm{~mm}$ face sheet thickness. This difference was increased due to the fact that more energy was absorbed by thicker facesheet and less energy was dissipated to bottom facesheet. Energy absorbed by reinforced honeycomb with higher facesheet thickness was the maximum as compared with other samples. Energy absorbed by reinforced honeycomb core and facesheet were 3.8 and $4.2 \mathrm{~kJ}$ for 1 
$\mathrm{mm}$ while that for $0.5 \mathrm{~mm}$ thick facesheet energy absorbed were 2.9 and $3.5 \mathrm{~kJ}$. Facesheet tends to absorb more energy than reinforced honeycomb core, see Fig. 12.

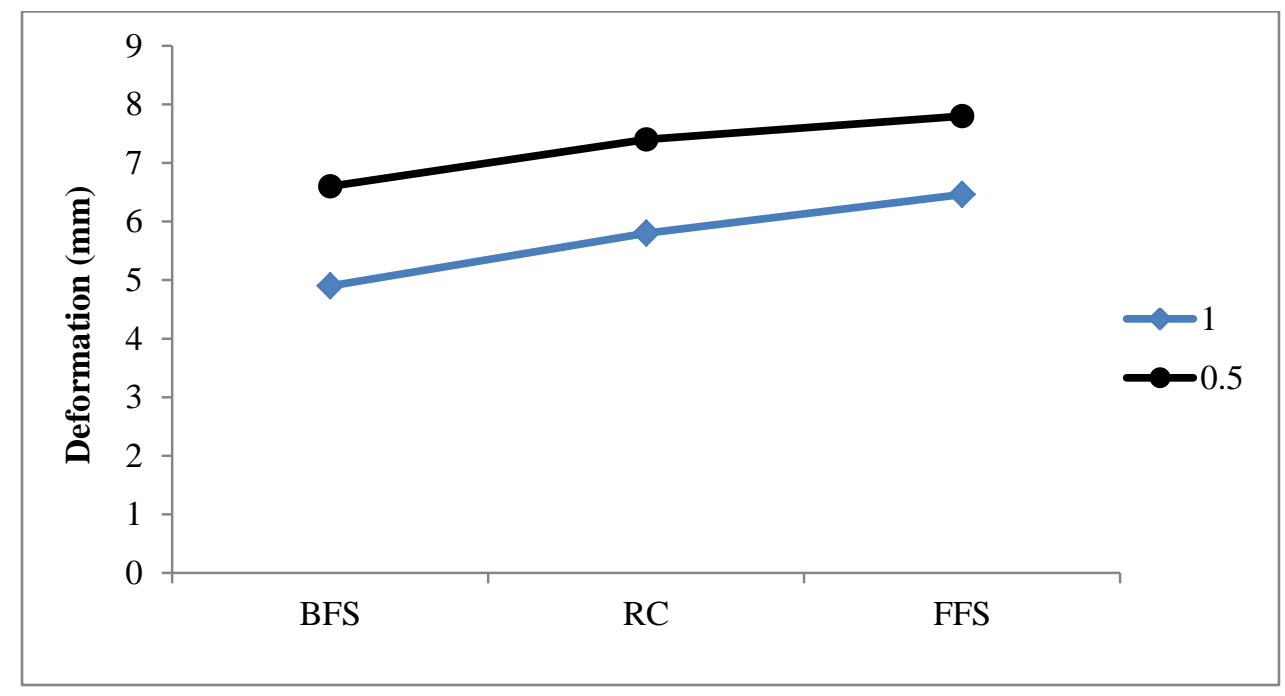

Figure12. Variation of deformation of reinforced honeycomb core with facesheet thickness

\section{CONCLUSIONS}

Performance of Reinforced honeycomb sandwich structure against blast load was evaluated to establish the blast resistance of such structure. Various parameters effecting blast performance of reinforced honeycomb structure were established in present study. Geometrical parameters like cell size, cell-wall thickness, facesheet thickness and node length (core thickness) effects the performance of reinforced honeycomb under blast loads. Some of the major findings attained from the study were:

1. Modes of deformation of reinforced honeycomb sandwich was divided into three major regions namely fully folded region, partially folded region and clamped region. Debonding of face sheets and reinforced honeycomb core and core crushing and densification were visible failures. 
2. Reinforced honeycomb had more blast resistance as compared to conventional honeycombs although modes of deformation of both cores were quite similar.

3. Increment in cell size reduces the blast resistance of reinforced honeycomb core sandwich structures. Back facesheet deformation of reinforced honeycomb of 7, 10 and $15 \mathrm{~mm}$ cell size honeycomb core was 4.96 .2 and $6.9 \mathrm{~mm}$ respectively

4. Blast resistance of reinforced honeycomb core was found in proportion with cell-wall thickness of the core. Reinforced honeycomb core sandwich with $0.4 \mathrm{~mm}$ thickness tends to have back facesheet deformation of $1.79 \mathrm{~mm}$ while with $0.1 \mathrm{~mm}$ thickness deformation was $4.9 \mathrm{~mm}$.

5. Node length (Core thickness) increase leads to increase in the blast resistance of reinforced core sandwich structure. Back facesheet deformation of reinforced honeycomb with $50 \mathrm{~mm}$ node length was $3.2 \mathrm{~mm}$ while that of $25 \mathrm{~mm}$ node length was $4.9 \mathrm{~mm}$.

6. Increase in mass of TNT directly increases the pressure intensity acting on the core structure which directly leading to more effects on the structure of blast loading. Back facesheet deformation increases from $2.24 \mathrm{~mm}$ to $2.46 \mathrm{~mm}$ on increase of mass of TNT from $10 \mathrm{~g}$ to $30 \mathrm{~g}$. 


\section{REFERENCES}

F. Mostert, 2018 "Challenges in blast protection research," Defence Technology.

K. Amini, W. Altenhof, S. C. K. Yuen, C. Opperman, and G. Nurick, 2017 "Experimental and numerical investigation on the deformation and energy dissipation of AA6061-T6 circular extrusion subjected to blast loading," International Journal of Impact Engineering, vol. 110, pp. 228-241.

A. Gargano, K. Pingkarawat, M. Blacklock, V. Pickerd, and A. Mouritz, 2017 "Comparative assessment of the explosive blast performance of carbon and glass fibre-polymer composites used in naval ship structures," Composite Structures, vol. 171, pp. 306-316.

K. Spiller, J. A. Packer, M. V. Seica, and D. Z. Yankelevsky, 2016 "Prediction of annealed glass window response to blast loading," International Journal of Impact Engineering, vol. 88, pp. 189200.

P. Del Linz, P. A. Hooper, H. Arora, Y. Wang, D. Smith and B. R. Blackman, 2017 "Delamination properties of laminated glass windows subject to blast loading," International journal of impact engineering, vol. 105, pp. 39-53.

X. Bai, L. Zhu, and T. Yu, 2017 "Saturated impulse for fully clamped square plates under blast loading," International Journal of Mechanical Sciences.

J. Marx, M. Portanova, and A. Rabiei, 2018 "A study on blast and fragment resistance of composite metal foams through experimental and modeling approaches," Composite Structures, vol. 194, pp. 652-661.

P. Zhang, J. Liu, Y. Cheng, H. Hou, C. Wang, and Y. Li, 2015 "Dynamic response of metallic trapezoidal corrugated-core sandwich panels subjected to air blast loading-An experimental study," Materials \& Design (1980-2015), vol. 65, pp. 221-230.

S. C. K. Yuen, G. Cunliffe, and M. du Plessis, 2017 "Blast response of cladding sandwich panels with tubular cores," International Journal of Impact Engineering, vol. 110, pp. 266-278.

G. McShane, V. Deshpande, and N. Fleck, "Underwater blast response of free-standing sandwich plates with metallic lattice cores," International Journal of Impact Engineering, vol. 37, pp. 11381149, 2010.

L. Jing, Z. Wang, V. Shim, and L. Zhao, 2014 "An experimental study of the dynamic response of cylindrical sandwich shells with metallic foam cores subjected to blast loading," International Journal of Impact Engineering, vol. 71, pp. 60-72.

X. Liu, X. Tian, T. Lu, and B. Liang, 2014 "Sandwich plates with functionally graded metallic foam cores subjected to air blast loading," International Journal of Mechanical Sciences, vol. 84, pp. 61-72.

M. Aleyaasin, J. Harrigan, and S. Reid, 2015 "Air-blast response of cellular material with a face plate: An analytical-numerical approach," International Journal of Mechanical Sciences, vol. 91, pp. 64-70.

M. Theobald, G. Langdon, G. Nurick, S. Pillay, A. Heyns, and R. Merrett, , 2010"Large inelastic response of unbonded metallic foam and honeycomb core sandwich panels to blast loading," Composite structures, vol. 92, pp. 2465-2475.

X. Li, P. Zhang, Z. Wang, G. Wu, and L. Zhao, 2014 "Dynamic behavior of aluminum honeycomb sandwich panels under air blast: Experiment and numerical analysis," Composite Structures, vol. 108, pp. 1001-1008.

F. Zhu, L. Zhao, G. Lu, and Z. Wang, 2008 "Deformation and failure of blast-loaded metallic sandwich panels-experimental investigations," International Journal of Impact Engineering, vol. 35, pp. 937-951. 
G. Nurick, G. Langdon, Y. Chi, and N. Jacob, 2009 "Behaviour of sandwich panels subjected to intense air blast-Part 1: Experiments," Composite Structures, vol. 91, pp. 433-441.

G. Langdon, G. Nurick, M. Y. Yahya, and W. Cantwell, 2010 "The response of honeycomb core sandwich panels, with aluminum and composite face sheets, to blast loading," Journal of Sandwich Structures \& Materials, vol. 12, pp. 733-754.

Y. Chi, G. Langdon, and G. Nurick, 2010 "The influence of core height and face plate thickness on the response of honeycomb sandwich panels subjected to blast loading," Materials \& Design, vol. 31, pp. 1887-1899.

Z. Fan, Y. Liu, and P. Xu, 2016 "Blast resistance of metallic sandwich panels subjected to proximity underwater explosion," International Journal of Impact Engineering, vol. 93, pp. 128135.

K. P. Dharmasena, H. N. Wadley, Z. Xue, and J. W. Hutchinson, 2008 "Mechanical response of metallic honeycomb sandwich panel structures to high-intensity dynamic loading," International Journal of Impact Engineering, vol. 35, pp. 1063-1074.

W. Huang, W. Zhang, D. Li, N. Ye, W. Xie, and P. Ren, 2016 "Dynamic failure of honeycomb-core sandwich structures subjected to underwater impulsive loads," European Journal of MechanicsA/Solids, vol. 60, pp. 39-51.

D. Karagiozova, G. Nurick, and G. Langdon, 2009 "Behaviour of sandwich panels subject to intense air blasts-Part 2: Numerical simulation," Composite Structures, vol. 91, pp. 442-450.

C. Qi, A. Remennikov, L.-Z. Pei, S. Yang, Z.-H. Yu, and T. D. Ngo, 2017 "Impact and close-in blast response of auxetic honeycomb-cored sandwich panels: experimental tests and numerical simulations," Composite Structures, vol. 180, pp. 161-178.

F. Zhu, L. Zhao, G. Lu, and E. Gad, 2009 "A numerical simulation of the blast impact of square metallic sandwich panels," International Journal of Impact Engineering, vol. 36, pp. 687-699.

H. Ebrahimi, R. Ghosh, E. Mahdi, H. Nayeb-Hashemi, and A. Vaziri, 2016 "Honeycomb sandwich panels subjected to combined shock and projectile impact," International Journal of Impact Engineering, vol. 95, pp. 1-11.

H. Ebrahimi, L. K. Someh, J. Norato, and A. Vaziri, 2018 "Blast-resilience of honeycomb sandwich panels," International Journal of Mechanical Sciences, vol. 144, pp. 1-9.

X. Jin, Z. Wang, J. Ning, G. Xiao, E. Liu, and X. Shu, 2016 "Dynamic response of sandwich structures with graded auxetic honeycomb cores under blast loading," Composites Part B: Engineering, vol. 106, pp. 206-217.

Z. Li, W. Chen, and H. Hao, 2018 "Blast mitigation performance of cladding using square domeshape kirigami folded structure as core," International Journal of Mechanical Sciences, vol. 145, pp. 83-95.

Y. Wang, W. Zhao, G. Zhou, and C. Wang, 2018 "Analysis and parametric optimization of a novel sandwich panel with double-V auxetic structure core under air blast loading," International Journal of Mechanical Sciences, vol. 142, pp. 245-254.

S. Li, X. Li, Z. Wang, G. Wu, G. Lu, and L. Zhao, 2016 "Finite element analysis of sandwich panels with stepwise graded aluminum honeycomb cores under blast loading," Composites Part A: Applied Science and Manufacturing, vol. 80, pp. 1-12.

S. Li, X. Li, Z. Wang, G. Wu, G. Lu, and L. Zhao, 2017 "Sandwich panels with layered graded aluminum honeycomb cores under blast loading," Composite Structures, vol. 173, pp. 242-254.

G. Tiwari, T. Thomas, and R. Khandelwal, 2018 "Influence of reinforcement in the honeycomb structures under axial compressive load," Thin-Walled Structures, vol. 126, pp. 238-245.

Q. He, D. Ma, Z. Zhang, and L. Yao, 2015 "Mean compressive stress constitutive equation and crashworthiness optimization design of three novel honeycombs under axial compression," International Journal of Mechanical Sciences, vol. 99, pp. 274-287. 
S. Tabacu and C. Ducu, 2018 "Experimental testing and numerical analysis of FDM multi-cell inserts and hybrid structures," Thin-Walled Structures, vol. 129, pp. 197-212.

J. O. Hallquist, 2006 "LS-DYNA theory manual," Livermore software Technology corporation, vol. 3, pp. 25-31.

D. Kakogiannis, D. Van Hemelrijck, J. Wastiels, S. Palanivelu, W. Van Paepegem and J. Vantomme, 2010 "Assessment of pressure waves generated by explosive loading," Computer Modeling in Engineering and Sciences (CMES), vol. 65, p. 75.

Z. Li, W. Chen, and H. Hao, 2018 "Numerical study of sandwich panel with a new bi-directional Load-Self-Cancelling (LSC) core under blast loading," Thin-Walled Structures, vol. 127, pp. 90101.

N. Mehreganian, L. Louca, G. Langdon, R. Curry, and N. Abdul-Karim, 2018 "The response of mild steel and armour steel plates to localised air-blast loading-comparison of numerical modelling techniques," International Journal of Impact Engineering, vol. 115, pp. 81-93.

T. Ngo, P. Mendis, A. Gupta, and J. Ramsay, 2007 "Blast loading and blast effects on structuresan overview," Electronic Journal of Structural Engineering, vol. 7, pp. 76-91.

M. D. Goel, V. A. Matsagar, A. K. Gupta, and S. Marburg, 2012 "Review of Blast Wave Parameters," Defence Science Journal, vol. 62, pp. 300-306.

T Thomas and G Tiwari, 2019, "Crushing behavior of honeycomb structure: A review" International journal of crashworthiness, vol. 24, pp 555-579. 